\title{
Destete artificial en ovinos: respuesta de estrés y bienestar animal. Revisión
}

\author{
Artificial weaning in sheep: stress response and \\ animal welfare. Review
}

\author{
Aline Freitas-de-Meloa, Rodolfo Ungerfeldb
}

\begin{abstract}
RESUMEN
El vínculo oveja-cordero se establece al parto y cambia a lo largo del periodo de lactación hasta el destete natural. El destete artificial es un manejo frecuentemente utilizado en los diferentes tipos de sistemas de producción ovina, que es realizado más tempranamente que el destete natural. Es uno de los eventos más estresantes en la vida del animal, ya que genera cambios fisiológicos y de comportamiento fuertemente indicadores de estrés, pudiendo afectar negativamente la salud y el bienestar animal tanto de ovejas como de corderos, así como los resultados productivos. La presente revisión sintetiza y analiza información sobre cómo se establece el vínculo madre-cría, el desarrollo del mismo durante el período de lactación y el proceso de destete natural, así como los cambios que se producen cuando el destete se adelanta artificialmente. Además, se describe la respuesta generada por el destete artificial y qué factores la afectan, a nivel fisiológico, de comportamiento y productivo. Por último, se presenta la información existente sobre posibles estrategias que permitan minimizar los efectos negativos del estrés de destete artificial. Se agrega información original sobre cómo la variación cualitativa y cuantitativa de la oferta de pastura en los sistemas extensivos de producción ovino pueden afectar la respuesta de destete de los corderos, y manejos con potencialidad práctica que pueden mitigar la respuesta al destete artificial. Se especifican aspectos en los que existe necesidad de investigación para mejorar la comprensión y desarrollar alternativas sobre cómo modular la respuesta de estrés al destete.
\end{abstract}

PALABRAS CLAVE: Amamantamiento, Comportamiento maternal, Corderos, Lactación, Ovinos.

\begin{abstract}
The establishment of ewe-lamb bond occurs at lambing, and is modified along the lactation period until natural weaning. Artificial weaning is a management commonly used in sheep productive systems commonly performed before natural weaning. Artificial weaning provokes strong behavioral and physiological responses indicative of stress, and is considered as one of the most stressful situations in the life of the animal. Those responses negatively affect animal health and welfare, and the productive results. Therefore, it is important to elucidate which factors affect those responses, and to develop strategies to decreases the negative response. This review summarizes the available information on the establishment of ewe-lamb bonding, and how this bond evolves during the lactation period until natural weaning. Moreover, it describes the behavioral and physiological stress responses to artificial weaning, and the main factors that affect those responses at physiological, behavioral and productive levels. Finally, it presents information on some strategies available to decrease the negative effects of artificial weaning. Includes original information on the influence of quantitative and qualitative changes of pasture allowance in extensive sheep production systems and the stress responses of lambs to weaning; and handlings that potentially may be applied to decrease the stress response to artificial weaning. It suggests whether is room to study and to develop practical alternatives to modulate the stress response to weaning.
\end{abstract}

KEY WORDS: Suckling, Maternal behavior, Lambs, Lactation, Ovine.

Recibido el 13 de marzo de 2015. Aceptado el 13 de septiembre de 2015.

a Departamento de Biología Molecular y Celular, Universidad de la República, Lasplaces 1620, Montevideo (11600), Uruguay , tel.: (598) 26221195, alinefreitasdemelo@hotmail.com. Correspondencia al primer autor.

b Departamento de Fisiología, Facultad de Veterinaria, Universidad de la República, Lasplaces, Uruguay. 
Los ovinos se caracterizan por presentar un vínculo madre-cría altamente selectivo, el que se establece inmediatamente después del parto(1). La intensidad del vínculo cambia a lo largo del periodo de lactación, a medida que se produce la independencia gradual del cordero hasta el destete natural(2). El destete artificial se realiza más tempranamente, y es caracterizado por el reemplazo completo del amamantamiento por la cría artificial con leche o la sustitución de la leche por alimentos sólidos $(2,3,4)$. Este manejo implica la separación de la oveja y su cordero, además de cambios nutricionales para el cordero, y del ambiente físico (comúnmente los corderos y las ovejas son llevados a potreros diferentes) y social (un ambiente que estaba formado por ovejas y corderos, será formado por solamente corderos u ovejas)(2). La edad del destete artificial varía según el objetivo productivo, siendo realizado tempranamente ( 0 - 2 días) en los sistemas ovinos de producción de leche(4), y de acuerdo a nuestro conocimiento entre los 60 y 150 días en los sistemas dirigidos a la producción de carne y lana.

El destete genera una respuesta de estrés tanto en la oveja como en su cordero, la que produce cambios fisiológicos y de comportamiento. La intensidad de la respuesta al destete artificial, y las consecuencias del mismo sobre la producción y el bienestar de los animales varía de acuerdo a la intensidad del vínculo con la madre durante el período anterior al destete, la edad de los corderos, el sexo de las crías, la raza y la alimentación de las ovejas durante la gestación y la lactancia $(5,6,7)$. En ovinos se ha estudiado la respuesta productiva y los efectos negativos producidos por diferentes tipos de destete: abrupto, progresivo, en etapas, y alambrado de por medio (colocación de ovejas y corderos separados por un alambrado durante varios días antes de la separación definitiva) $(6,8,9,10)$. De acuerdo a una serie de trabajos realizados, el destete abrupto a pesar de ser el más utilizado, y el destete realizado con alambrado de por medio, son los que generan mayores respuestas de estrés al
Sheep are characterized by a highly selective mother-lamb bonding, which is set immediately after lambing(1). The intensity of the bond changes throughout the lactation period, as the process of natural weaning advances and thus, the lamb gains independence(2). Artificial weaning is performed earlier, and is characterized by the complete replacement of suckling by artificial rearing with milk, or milk substitution by solid food $(2,3,4)$. This management implies the separation of ewe and her lamb, in addition to nutritional changes to the lamb, and changes of the physical (commonly the lambs and sheep are taken to different paddocks) and social environments (an environment that was made up of sheep and lambs, will be formed by only lambs or ewes)(2). Age of artificial weaning varies according to the productive objective, being done early (0-2 d) in dairy sheep(4), and according to our knowledge between 60 and $150 \mathrm{~d}$ in extensive systems aimed at meat and wool production.

Weaning generates a stress response in ewes and their lambs that produces physiological changes and behavior. The intensity of the response to artificial weaning, and the consequences on production and welfare of the animals vary according to the intensity of the bond with the mother during the weaning period, the age of lambs, the sex of the offspring, breed and feeding of ewes during pregnancy and lactation $(5,6,7)$. There is information of the productive response and the negative effects produced by different types of weaning: abrupt, progressive, in stages, and through fencelines (placement of sheep and lambs, separated by a fence during several days before the final separation $)(6,8,9,10)$. According to a series of studies, the abrupt weaning, despite being the most widely used weaning together with fenceline weaning, seem to be the systems that generate greater stress responses to weaning. In some studies management systems prior to weaning to decrease the stress response in sheep have been assessed. 
destete. También se han realizado trabajos para evaluar qué manejos previos al destete pueden disminuir la respuesta de estrés en ovinos.

Si bien el estrés de los animales es evidente a nivel de campo, la bibliografía científica es aún escasa y dispersa. Esta revisión sintetiza información sobre los cambios fisiológicos y de comportamiento al destete, tanto en las ovejas como en los corderos, y las repercusiones negativas que esto tiene sobre el bienestar animal y los resultados productivos. A su vez se sintetiza la información disponible sobre los principales factores que influyen en la respuesta de estrés al destete, y se analizan algunos manejos alternativos que logran disminuir los efectos negativos.

\section{Establecimiento del vínculo madre-cría}

El vínculo entre la oveja y el cordero se despliega inmediatamente del parto. El comportamiento maternal es inducido por los cambios endocrinos que ocurren en la oveja durante el periparto, principalmente la disminución de la concentración de progesterona (P4) y el aumento de las concentraciones de estrógenos y oxitocina $(11,12)$. En respuesta a esos cambios, y solo en este período, la oveja tiene una fuerte atracción hacia el líquido amniótico que recubre al cordero(13). El comportamiento de limpieza del cordero desplegado durante los primeros 20-30 min ayuda a la madre a reconocer a su cría(14). Pasados los 60 a 120 min, si la madre recibe una cría diferente de la suya o si no ha reconocido previamente a su cría, la rechaza(14). Las ovejas solo dirigen su comportamiento maternal hacia los corderos que identificaron como su progenie en esos primeros minutos posparto(15). Por eso, para que el vínculo se mantenga es importante que el cordero y la madre sepan identificarse entre otros animales del grupo. El olfato es importante en la formación de la memoria de la madre hacia su cría, pero la madre también reconoce a su cría a través de la audición y visión(16).

Los primeros comportamientos desplegados por los corderos luego del parto llevan al
While the stress of animals is evident at the field level, the scientific literature is still scarce and scattered. This review summarizes information about the physiological changes and behavioral responses to weaning, from both ewes and lambs, and the negative impact that this has on animal welfare and productive results. In turn, the information available on the main factors influencing the stress response to weaning is summarized, and some alternative management to decrease the negative effects are analyzed.

\section{Establishment of the mother-lamb bond}

The link between the ewe and the lamb is displayed immediately lambing. Maternal behavior is induced by endocrine changes that occur in ewes during the peripartum period, mainly the decrease in the progesterone (P4) concentration and the increase on estrogen and oxytocin concentrations $(11,12)$. In response to these changes, and only in this period, the ewe is strongly attracted to the amniotic fluid that surrounds the lamb(13). Cleaning of the lamb during the first 20 to 30 min helps the mother to recognize her offspring(14). After 60 to 120 min, if the mother receives a different offspring from her own or if she has not previously recognized her lamb, she rejects it(14). The ewe only directs her maternal behavior toward the lambs that were identified as their own offspring during the first postpartum minutes(15). Therefore, to keep the bond it is important that the lamb and the mother can identify each other among other animals in the group. Smell of the offspring is important for the memory of the mother, but the mother also recognizes her lamb through hearing and vision(16).

The first behaviors displayed by the lambs after birth lead to reach the teat and suckle(13). If the mother accepts her offspring to suckle means that she has recognized it and accepted as her own(17). Lambs also recognizes their mother through sensory mechanisms, primarily hearing and vision(18), which increases the 
amamantamiento(13). Si la madre acepta que su cría mame significa que la reconoció y la aceptó como propia(17). El cordero también reconoce a su madre a través de mecanismos sensoriales, principalmente la audición y la visión(18), lo que aumenta sus probabilidades de sobrevivencia(19). El vínculo madre-cría durante el posparto inmediato se caracteriza por una alta frecuencia de amamantamientos y una fuerte tendencia de la díada a mantenerse físicamente cerca(20,21). Aunque separaciones temporarias de corta duración durante este período no tienen consecuencias sobre el vínculo madre-cría posterior(13), pueden generar cambios de comportamiento transitorios en la madre. Por ejemplo, las ovejas pueden alejarse de la cría ante la presencia humana(22).

\section{Destete natural}

El destete natural se caracteriza por el reemplazo de la leche por comida sólida, y por la independencia social de la cría(2). Durante las primeras dos semanas de vida las ovejas permiten al cordero mamar todas las veces que ellos lo requieren y gradualmente, a medida que la lactación avanza, lo van impidiendo más frecuentemente(23). A lo largo del periodo de lactación y a medida que el cordero crece, la frecuencia de amamantamientos disminuye y la distancia física entre la oveja y el cordero aumenta(20,21). Al mismo tiempo, la cría se va familiarizando y adaptando a la ingestión de alimentos sólidos(2). La disminución de la frecuencia de amamantamientos también está asociada a un mayor desarrollo ruminal(24). Por ejemplo, en corderos Santa Inés el desarrollo del rumen se completa al alcanzar los $15 \mathrm{~kg}$ de peso(25), lo que implica que el cordero está apto para el cambio de dieta.

La producción de leche de las ovejas es uno de los principales factores que determina la edad del destete natural de sus corderos(26). La edad del destete natural también puede variar de acuerdo a la situación nutricional de las ovejas, uno de los factores que más afecta es la producción de leche de la madre(27). El chances of survive(19). During the immediate postpartum period the mother-lamb bond is characterized by a high frequency of suckling and a strong tendency to be in physical proximity during the day $(20,21)$. Although temporary separations of short duration during this period do not have consequences on the later mother-lamb bond(13), they can generate transient behavior changes in the mother. For example, ewes can move away from their lamb when humans are present(22).

\section{Natural weaning}

Natural weaning is characterized by the replacement of milk by solid food and the acquisition of social independence of the lamb(2). During the first 2 wk of the life, ewes allow lambs to suckle every time they require it and gradually, as the lactation proceeds, rejection is more frequent(23). During the period of lactation and the lamb growth, suckling frequency decreases at time that the physical distance between the ewe and lamb increase $(20,21)$. At the same time, the lamb is familiarized and adapted to the consumption of solid food(2). The decrease of the suckling frequency is also associated with rumen development(24). For example, in Santa Inés lambs, rumen development is achieved when lambs reach approximately $15 \mathrm{~kg}$ of weight(25), allowing the lamb to change the diet.

The production of ewes' milk is one of the main factors that influence the age of the natural weaning of their lambs(26). Age of natural weaning may also vary according to the nutritional status of the ewes; one of the factors that mostly affect is mother's milk production(27). Suckling ends with the weaning of the lamb, about 4 to 5 mo of age(26).

\section{Artificial weaning}

Artificial weaning is the forced end of suckling, the end of milk supply by the ewes to their lambs, and usually involves physical separation, and therefore the loss of the mother $(2,3,4)$. Artificial weaning is commonly applied in sheep 
DESTETE ARTIFICIAL EN OVINOS: RESPUESTA DE ESTRÉS Y BIENESTAR ANIMAL

amamantamiento finaliza con el destete espontáneo del cordero, a partir de los 4 a 5 meses de $\operatorname{edad}(26)$.

\section{Destete artificial}

El destete artificial es la finalización forzada de la succión y por tanto de la obtención de la leche por parte de la cría, y generalmente incluye la separación, y por tanto la pérdida de la madre $(2,3,4)$. El destete artificial se aplica normalmente en los sistemas de producción ovina, ya que mejora los resultados reproductivos y productivos. En la producción de ovinos de carne y lana el destete se realiza para mejorar la condición corporal y peso, ya que los mismos influyen de manera positiva en las tasas de concepción, prolificidad, peso de los corderos al parto y al destete $(28,29)$. En los sistemas de producción ovina de leche el destete artificial se realiza tempranamente para la utilización de la leche para la fabricación de productos lácteos, y está asociado a la cría artificial de los corderos con sustitutos lácteos(4).

El momento del destete artificial varía según el objetivo de cada establecimiento ovino. El momento en que se realiza el destete artificial también va a depender de la edad, peso y habilidad del cordero en comer alimentos sólidos(4). De acuerdo al objetivo productivo, el destete puede ser realizado desde las $24 \mathrm{~h}$ posparto hasta cerca de la edad del destete natural. Los establecimientos de producción lechera mantienen la oveja con su cordero por 24 a 48 h para permitir la ingestión del calostro, para luego realizar un destete abrupto(4). En algunos establecimientos de producción de leche ovina el cordero continúa accediendo a la madre durante tiempos reducidos, permitiendo un amamantamiento restringido. Comúnmente los productores ovinos de carne y lana realizan un destete entre los 60 y 150 días de edad, aunque lo más frecuente es que sea antes de los 120 días, momento en que el cordero ya incrementó el consumo de alimentos sólidos luego del pico de lactación que se da en la $3^{a}$ a 4a semana $^{2}$ posparto. En este caso, el productor realiza la production systems, since it improves the reproductive and productive results. In meat and wool sheep production, weaning is done to improve body condition and weight, since they influence positively the conception rates, prolificacy and weight of lambs at birth and at weaning $(28,29)$. In sheep milk production systems artificial weaning is done early to obtain more milk, and is associated with the artificial rearing of lambs with dairy substitutes(4).

Artificial weaning time varies depending on the purpose of each sheep farm, and depends on age, weight and ability of the lamb to eat solid food(4). According to the productive purpose, lambs can be weaned from $24 \mathrm{~h}$ postpartum until the age of their natural weaning. Dairy farms maintain ewes and lambs together for 24 to $48 \mathrm{~h}$ to allow lambs to suckling colostrum, and then make an abrupt weaning(4). On some farms of sheep milk, lambs continue accessing their mother during short periods of time, allowing a restricted suckling. Commonly, sheep meat and wool farmers wean their lambs between 60 to $150 \mathrm{~d}$ of age, but most often before $120 \mathrm{~d}$, moment in which the lamb already increased the intake of solid food, and after the lactation peak that occurs in the 3rd to 4rd wk postpartum. In this case, farmers separate ewes and lambs without needing artificial rearing, making easier handling, and reducing costs.

\section{Stress response to artificial weaning}

The abrupt and complete separation of the lambs before the natural weaning age is a stressful situation for ewes and lambs, which is caused by different stressors: 1) Emotional, generated by the end of the mother-lamb bond; 2) Changes in the physical and social environment, since at least one of the two is housed in a new environment, often with other animals with which they had no previous contact; 3) End of suckling, which implies the end of the neurophysiological changes induced by suckling and 4) Nutritional change, generated by the loss of milk and its complete replacement 
separación de la oveja y su cordero sin la necesidad de la cría artificial, facilitando el manejo y reduciendo los costos de producción.

\section{Respuesta de estrés al destete artificial}

La remoción abrupta y completa de los corderos antes de la edad del destete natural es una situación estresante para la oveja y para el cordero, provocada por diferentes estresores:

1) emocional, generado por la ruptura del vínculo madre-cría; 2) cambios en el ambiente físico y social, ya que al menos uno de ambos es alojado en un nuevo ambiente, muchas veces con otros animales con los que no tenía contacto previo; 3) cese de la succión, lo que implica el cese de los cambios neurofisiológicos inducidos por la misma; y 4) cambio nutricional, generado por la pérdida de la leche y su sustitución completa por otros alimentos $(2,10,30)$. La respuesta del animal es consecuencia de todos estos estresores en conjunto, pero la importancia relativa de cada uno ha sido escasamente estudiada. Luego de la separación, la oveja y el cordero aumentan la frecuencia de comportamientos relacionados a la búsqueda del otro. Se observa un aumento de la frecuencia de vocalizaciones(9) y del tiempo que pasan parados y caminando, además de que frecuentemente costean (cuando los animales se mueven repetidas veces a 1 a 2 m de manera paralela al alambrado modificando la dirección de ida y vuelta en forma continua), comportamiento que en los corderos se asocia exclusivamente a la pérdida de la madre(30). El aumento en la cantidad de vocalizaciones y el despliegue del comportamiento costear son los cambios de comportamiento más indicativos de la respuesta de estrés al destete. Generalmente estos cambios se producen rápidamente, alcanzan su máxima frecuencia en pocas horas, y se manifiestan durante 3 a 4 días. El rápido cese de estos comportamientos podría estar relacionado a su falta de efectividad, ya que generan un importante costo sin lograr respuestas positivas $(10,31)$. Además, al aumentar los comportamientos relacionados con la búsqueda de la cría o de la madre, las ovejas by other food $(2,10,30)$. The response of the animal is the result of these stressors altogether, but the relative importance of each one has been poorly studied. After separation, ewes and lambs increase the frequency of behaviors related to searching the other. There is an increase in the frequency of vocalizations $(9)$ and at the same time standing and walking, as well as pacing (when animals walk again and again at a distance of 1 to $2 \mathrm{~m}$ parallel to the fence, modifying the direction of back and forth continuously), behavior that in lambs is exclusively associated with the loss of the mother(30). The increase in the number of vocalizations and pacing are behavioral changes more closely related to the stress response to weaning. Usually these changes occur quickly, reaching their maximum frequency in few hours, and lasting 3 to $4 \mathrm{~d}$. The rapid end of these behaviors could be related to their lack of effectiveness, since they generate important costs without achieving positive responses $(10,31)$. In addition, the increase breeding of the ewe and the lamb search-related behaviors, both reduce the feeding and resting time: the animals spend less time laying, grazing and ruminating after weaning $(10,30,32)$. In recently weaned lambs fed on pastures or with dairy substitutes, some lambs redirect the suckling behavior trying to suck from other lambs(33).

The loss of the mother as a result of weaning is a main factor in the response of lamb's stress. Damian et $a(30)$ compared the stress response of lambs at weaning if they were reared artificially with sheep's milk supplied in artificial teats or reared by their mothers. At weaning and when artificial rearing ended, only the lambs who lost their mother paced, and walked and vocalized more, decreasing the time grazing. This shows that these behaviors are mainly affected by the loss of the mother, and to a lesser extent by the loss of milk suckling and the change of feeding as a whole.

Weaning also produces acute physiological changes indicators of stress in ewes and lambs, as a rapid increase in the serum concentration 
y corderos reducen los comportamientos de alimentación y descanso: los animales pasan menos tiempo echados, pastando y rumiando luego del destete(10,30,32). En corderos recién destetados alimentados en base a pasturas 0 con sustitutos lácteos, se ha observado que algunos corderos redirigen el comportamiento de succión intentando mamar de otros corderos(33).

La pérdida de la madre como consecuencia del destete es un factor central en la respuesta de estrés de los corderos. Damián et a)(30) compararon la respuesta de estrés al destete de corderos criados artificialmente con leche ovina suministrada en ubres artificiales y corderos criados por sus madres. Al destete y cuando cesó la cría artificial (desleche) se observó que solamente los corderos que perdieron la madre desplegaron el comportamiento de costear, y dedicaron más a caminar y vocalizar, disminuyendo el tiempo pastando. Esto demuestra que estos comportamientos están afectados mayormente por la pérdida de la madre, y en menor medida por la pérdida de la leche, la succión y el cambio de alimentación en su conjunto.

El destete también provoca cambios fisiológicos agudos indicadores de estrés en las ovejas y corderos, como un aumento rápido en la concentración sérica de cortisol(34,35), que es uno de los principales indicadores endocrinos de la respuesta de estrés en ovinos( 36,37$)$. El aumento de la secreción de cortisol está asociado con la modulación de la respuesta inmune del animal(38), ya que en los rumiantes se ha reportado que el destete artificial afecta negativamente la función inmune $(39,40,41)$. Más aún, la cantidad de anticuerpos sintetizados luego de un desafío antigénico es menor en los corderos durante el período posdestete que en otros momentos(42). Luego del destete en las ovejas se observa un aumento de los leucocitos(8), y una disminución de la concentración de proteínas totales y globulinas(10). Dado que el destete es un manejo estresante y que afecta el sistema inmune, puede aumentar la of cortisol(34,35), which is one of the main endocrine indicators of the stress response in sheep $(36,37)$. The increase in the secretion of cortisol is associated with modulation of the immune response of the animal(38), since in ruminants, it has been reported that artificial weaning impairs immune function $(39,40,41)$. Moreover, the amount of antibodies synthesized after an antigenic challenge is lower in the lambs during the postweaning than at other times(42). After weaning, there is an increase in the number of leukocytes $(8)$, and a decrease in the concentration of total proteins and globulins of the ewe $(10)$. As weaning is a stressful management that affects the immune system, the animals may be more susceptible to diseases. For example, lambs recently weaned and experimentally infected with Haemonchus contortus and Trichostrongylus colubriformis had more eggs of these parasites, lower hematocrit, and a posterior lower production of antibodies against these parasites than unweaned controls(43). It has also been reported that weaning naturally increases the excretion of coccidia oocysts $(8,9)$.

Weaning also affects negatively the growth of the lambs, and if they are not artificially reared, this effect may be even greater in lambs weaned before ending the development of the rumen $(44,45)$. This delay in growth could also be explained as a consequence of the worst immune status and increased susceptibility to gastrointestinal parasites, as well as changes of behavioral indicators of stress $(8,30,43)$. In synthesis, the behavioral changes and the physiological responses have negative consequences both at production and on welfare of animals, so it is important to develop alternatives to decrease them.

Factors affecting the response to separation of the ewe and her lamb

There are many factors that can influence the intensity of the response to the separation of the ewes and their lambs, as age, sex, genetics and feeding of the sheep during pregnancy. The excitement and the frequency of 
susceptibilidad del animal a enfermedades. Por ejemplo, corderos recientemente destetados e infectados experimentalmente con Haemonchus contortus y Trichostrongylus colubriformis presentaron una mayor cantidad de huevos de estos parásitos, menor hematocrito, y una menor producción posterior de anticuerpos contra estos parásitos que los controles no destetados(43). Asimismo, se ha reportado que el destete provoca naturalmente un aumento de la excreción de ooquistes de $\operatorname{coccidios}(8,9)$.

El destete también afecta negativamente el crecimiento de los corderos, el que puede ser más marcado en los corderos destetados antes de completar el desarrollo del rumen si no son criados artificialmente $(44,45)$. Este retraso en el crecimiento también podría ser explicado como consecuencia del peor estatus inmunológico y el aumento de la susceptibilidad a parasitosis gastrointestinales, además de los cambios de comportamiento indicadores de estrés $(8,30,43)$. En síntesis, los cambios de comportamiento y las respuestas fisiológicas tienen consecuencias negativas tanto a nivel productivo como en el bienestar de los animales, por lo que es importante desarrollar alternativas para disminuirlas.

Factores que afectan la respuesta a la separación de la oveja y su cordero

Existen muchos factores que pueden influir sobre la intensidad de la respuesta a la separación de la oveja y su cordero, como la edad, el sexo, la genética y la alimentación de la oveja durante la gestación.

La agitación y la frecuencia de vocalizaciones fueron mayores luego del destete en corderos de 2 que de 4 meses(6). Los mismos autores observaron los mismos cambios de comportamiento, y una menor tasa de crecimiento de los corderos cuando el destete se realizó a las 13 que a las 16 semanas(46).

El efecto de la edad al destete sobre el crecimiento de los corderos ha sido ampliamente estudiado $(44,45,47,48)$. De manera general lo que vocalizations are greater after weaning lambs at 2 than at $4 \mathrm{mo}(6)$. The same authors observed the same behavioral changes, and a lower growth rate of the lambs when they weaned them at 13 to $16 \mathrm{wk}^{(46)}$.

The effect of age at weaning on the growth of the lambs has been widely studied $(44,45,47,48)$. In general, the rate of growth is more affected when weaning is performed earlier, which is probably due to a slower adaptation to solid food intake in younger lambs(49). In addition, mortality rates at $210 \mathrm{~d}$ were greater in lambs weaned at $45 d$ than at 60 and $75 d(50)$. These results indicate that at a younger age, when the ewe-lamb bond is stronger, and lambs have a greater social and nutritional dependence, the negative effects of weaning on the lambs' welfare are greater.

It has also been determined that female lambs have stronger lamb-ewe bonds and greater responses to stressors than male lambs $(51,52,53)$. In domestic sheep without limitations in the availability of food, abrupt weaning affected more the susceptibility to parasites and the growth rate of females than males $(5,9)$. On the other hand, mountain sheep lambs (Bighorn) males weaned 2 to $4 \mathrm{wk}$ before the estimated time of the natural weaning, showed slower growth until puberty than those that remained with their mothers, but females were not affected(54). This study was performed in natural conditions, where changes in the quality and quantity of available nutrients change throughout the year, having periods with strong feed limitations. This, together with the greater growth rate and energy demand of males, could explain the difference between male and female lambs. In general, although it has been reported that there are differences in susceptibility to parasites and the response of the immune system according to the gender of the offspring $(55,56,57)$, information about the factors that differentially affect males and females in response to artificial weaning is still insufficient. 
se ha observado es que cuanto menor es la edad al destete más se afecta la tasa de crecimiento, lo que probablemente sea debido a una adaptación más lenta al consumo de alimentos sólidos de los corderos más jóvenes(49). Además, corderos destetados a los 45 días de edad presentaron mayor mortalidad y fueron más livianos a los 210 días que los destetados a los 60 y 75 días(50). Estos resultados indican que a menor edad, más fuerte es el vínculo oveja-cordero, y mayor es la dependencia social y nutricional de las crías, y por lo tanto las repercusiones negativas del destete sobre el bienestar de los corderos.

También se ha determinado que las corderas presentan mayor intensidad de vínculo madrecría y mayor respuesta a estresores que los machos $(51,52,53)$. En ovinos domésticos sin limitantes en la disponibilidad de alimento, el destete abrupto afectó más la susceptibilidad a parásitos y la tasa de crecimiento de las hembras que la de los machos $(5,9)$. Contrariamente, corderos machos de ovejas de montaña (Big Horn) destetados 2 a 4 semanas antes del tiempo estimado del destete natural presentaron menor crecimiento hasta la pubertad que los que permanecieron con sus madres, pero las hembras no se vieron afectadas(54). Este trabajo se realizó en condiciones naturales, donde los cambios en la calidad y cantidad de nutrientes disponibles cambia a lo largo del año, habiendo periodos con fuertes limitantes de alimento. Esto, sumado a que los machos generalmente presentan una mayor tasa de crecimiento y demanda energética, podría explicar la diferencia entre corderos y corderas. De manera general, si bien se ha reportado que existen diferencias en la susceptibilidad a parásitos y en la respuesta del sistema inmune según el sexo de la cría $(55,56,57)$, la información sobre los factores que afectan diferencialmente a los corderos y las corderas en la respuesta al destete artificial es aún insuficiente.

Corderos de diferentes razas presentan diferentes tasas de desarrollo, por lo que también van a diferir en los ritmos de avance del destete natural, y por tanto la respuesta al
Lambs of different breeds have different growth rates, implying different degrees of advance in their natural weaning, and therefore the response to artificial weaning. Rhoenschaf lambs vocalized more at weaning than Merino lambs(58), which can be explained by the greater body development of this last(58). Similarly, F1 Texel by Corriedale lambs showed greater body weight and more rumination after weaning than pure Corriedale lambs, despite being both reared by Corriedale mothers $(59,60)$.

The feeding level of the mother during pregnancy or after parturition can also affect the response of the lambs at weaning. Important feed restriction during pregnancy adversely affects the mother-lamb bond at lambing(61) delays mother-lamb recognition(62), and may alter the natural weaning process. Recently, it was observed that ewes maintained with food restriction before conception until the last third of gestation had lower body weight during pregnancy and produced less milk in the postpartum(7)(Freitas-de-Melo A, Ungerfeld $R$ and Pérez-Clariget $R$, unpublished data). Lambs born from feed-restricted ewes grazed more before weaning, vocalized less and presented minor changes in the concentrations of albumin after weaning(63)(Freitas-de-Melo A, Ungerfeld $R$ and Pérez-Clariget $R$, unpublished data). Probably the lambs of ewes that had better nutrition during pregnancy were more stressed because they had more losses at weaning, since in addition to the mother, they lost a greater quantity of milk in an age in which consumption is still important. Another no opposed explanation is that lambs born from undernourished ewes had advanced their natural weaning process, since they presented a greater frequency of grazing before weaning probably to compensate the access to less milk amounts.

\section{Types of artificial weaning}

In sheep the available published scientific information relating ewe-lamb bond before weaning and the stress response is scarce. There are commonly four types of artificial weaning: abrupt, progressive, in steps with 
destete artificial. Se determinó que corderos de la raza Rhoenschaf vocalizaron más al destete que los corderos de la raza Merino(58), lo que puede ser explicado por el mayor desarrollo corporal de estos últimos(58). De manera similar, corderos Texel por Corriedale F1 presentaron mayor peso corporal y rumiaron más luego del destete, que corderos Corriedale puros, a pesar de ser ambos criados por madres Corriedale $(59,60)$.

El nivel de alimentación de la madre durante la gestación o luego de la misma también puede afectar la respuesta de los corderos al destete. Una restricción alimenticia importante durante la gestación afecta negativamente el vínculo madre-cría al parto(61) y retrasa el reconocimiento madre-cría(62), pudiendo alterar el proceso de destete natural. Recientemente se observó que las ovejas mantenidas con restricción alimenticia desde antes de la concepción hasta el tercio final de la gestación tuvieron un peso menor durante la gestación y una menor producción de leche en el posparto(7)(Freitas-de-Melo A, Ungerfeld $R$ y Pérez-Clariget $R$, datos no publicados). Los corderos hijos de las ovejas que sufrieron restricción alimenticia pastaban más antes del destete, vocalizaron menos y presentaron un menor cambio en las concentraciones de albúmina luego del destete(63)(Freitas-de-Melo $A$, Ungerfeld $R$ y Pérez-Clariget $R$, datos no publicados). Probablemente los corderos hijos de las ovejas que tuvieron un mejor plano nutricional durante la gestación se estresaron más porque tuvieron mayores pérdidas al destete, ya que además de la madre, perdieron una mayor cantidad de leche en una edad en que el consumo aún es importante. Otra explicación no contrapuesta es que los corderos hijos de las ovejas que sufrieron subnutrición hubieran adelantado su proceso de destete natural, ya que presentaron una mayor frecuencia de pastoreo antes del destete probablemente para compensar su dieta.

\section{Tipos de destete artificial}

En ovinos la información científica publicada disponible sobre cómo distintos manejos del restriction of the time accessing the mother, and in steps through a fenceline. The most commonly applied type is abrupt weaning, with a complete separation of the ewe and her lamb so there is no visual, auditory or olfactory contact after weaning(10).

Progressive weaning is the gradual separation of the ewe and her lamb to increase the time of separation until the complete separation. In this type of weaning, vocalizations increase in the first periods of temporary separation, but animals habituate to the separations, and therefore changes are not so intensive after definitive separation(8). However, progressive weaning has caused a greater sensitivity to the infestation of parasites before and after definitive weaning(8). According to these authors, the lambs had greater sensitivity to parasite infestation (weaning was done at $3 \mathrm{mo}$ ), so according to them, at this age is preferable to abrupt weaning so the increase in the infestation of parasites is not so great(8).

In weaning through fences animals can communicate, and thus visual, auditory and olfactory contact is maintained before the final separation(64). However, in this method lambs vocalized more the day of weaning, indicating greater stress than after abrupt weaning. Although females weaned from this method weighed more after weaning, they presented a smaller increase of the amount of coccidia that those weaned abruptly $(9)$, indicating that the immune response was adversely affected after the abrupt weaning.

There are some studies in two-steps weaning, in which during the first period the lambs are barred from suckling of the lamb covering the udder of the ewe, and in a second stage is the definitive separation. The lambs thus weaned responded with less agitation and vocalized less than abruptly weaned lambs(6).

Management to reduce the stress response to weaning

In addition to different types of weaning, there are some practices that can be applied before 
vínculo madre-cría previo al destete afectan la respuesta de estrés al destete es escasa. Se han evaluado cuatro tipos de destete artificial: abrupto, progresivo, en etapas con restricción en el tiempo de acceso a la madre, y alambrado de por medio. El tipo más común de destete artificial es el abrupto, donde se realiza la separación completa de la oveja y su cordero de forma que no hay contacto visual, auditivo ni olfativo luego del destete(10).

En el destete progresivo se realiza la separación gradual de la oveja y su cordero aumentando el tiempo de separación hasta la separación completa. En este tipo de destete se ha observado un aumento de las vocalizaciones en los primeros periodos de separación temporaria, pero los animales se acostumbran a las separaciones, y por tanto, cuando se realiza el destete definitivo los cambios de comportamiento no son tan intensos(8). Sin embargo, el destete progresivo ha provocado una mayor sensibilidad a la infestación de parásitos antes y después del destete definitivo(8). De acuerdo a estos autores los corderos presentaban una mayor sensibilidad a la infestación a parásitos (el destete fue realizado a los 3 meses), por lo que de acuerdo a los mismos, a esta edad es preferible el destete abrupto para que no aumente tanto la infestación(8).

En el destete realizado con un alambrado de por medio los animales se pueden comunicar, ya que se mantiene el contacto visual, auditivo y olfativo antes de la separación definitiva(64). Sin embargo, en este método de destete los corderos vocalizaron más al día del destete, lo que indica mayor respuesta de estrés que en el destete abrupto. Aunque las hembras destetadas a partir de este método pesaron más después del destete, presentaron un menor aumento de la cantidad de coccidios que las que se destetaron abruptamente( 9 ), lo que indica que la respuesta inmune se afectó negativamente luego del destete abrupto.

También se han estudiado los efectos del destete en dos etapas, en la primera se impide el or after weaning to reduce the response of ewes and lambs. Intravaginal devices used to synchronize estrus that release progesterone reduce the ewe response to weaning(10). With these treatments ewes vocalize and pace less frequently. In addition, the treatment moderated the decrease of total proteins concentration, due to a minor reduction of the globulin concentration. The values of serum globulins after weaning in the untreated ewes decreased more than in ewes treated, reaching levels of hipoglobulinemia, which could indicate a state of immuno-deficiency. Therefore, this treatment can reduce susceptibility to diseases of ewes after weaning.

Although this treatment reduced the stress response to weaning, its application is not practical, as the treatment is prolonged and expensive. For this reason, it was recently investigated whether treatment with injectable progesterone administered only the day of weaning reduces the response of stress in sheep, which would generate practical alternatives. This treatment reduced markedly the frequency of pacing and walking the day of weaning, and a tendency to reduce the frequency of vocalizations compared with the control group(65).

Other management that reduce the stress response is to induce estrus in the ewes by hormonal treatments the day of weaning, at the same time that rams are introduced(35). This management reduced the increase of vocalization frequency and the cortisol concentration at weaning, and may be easily included in accelerated lambing systems aimed to obtain pregnant ewes during the early postpartum period.

It is also important to consider the management of animals after weaning. The post-weaning social enrichment improves the welfare of lambs(66). The stress response of the lambs diminished when lambs remained for $1 \mathrm{~h}$ per day in close contact with a human who handled them gently (caressed them and spoke to them) 
amamantamiento del cordero cubriendo la ubre de la oveja, y en una segunda etapa se realiza la separación definitiva. Los corderos destetados de esta forma respondieron con menor agitación y vocalizaron menos que los destetados abruptamente(6).

Manejos para reducir la respuesta de estrés al destete

Además de diferentes tipos de destete, se han estudiado diferentes prácticas de manejo que pueden ser aplicadas antes, al día o luego del destete para disminuir la respuesta de estrés de ovejas y corderos. La aplicación de dispositivos intravaginales utilizados para sincronizar celos que liberan progesterona reduce la respuesta de estrés de las ovejas al destete(10). Con estos tratamientos se observa una menor cantidad de vocalizaciones y los animales realizaron menos frecuentemente el costeo. Además, el tratamiento moderó la disminución en las concentraciones de las proteínas totales, debido a una menor reducción de la concentración de globulinas. Los valores de globulinas séricas luego del destete en las ovejas no tratadas disminuyeron más que en las ovejas tratadas, alcanzando niveles de hipoglobulinemia, lo que podría indicar un estado de inmuno-deficiencia. Por lo tanto, este tratamiento puede reducir la susceptibilidad a enfermedades de las ovejas después del destete.

Si bien este tratamiento redujo la respuesta de estrés al destete, su aplicación no es viable desde el punto de vista práctico, ya que el tratamiento es prolongado y costoso. Por eso, recientemente investigamos si un tratamiento con progesterona inyectable administrada solamente el día del destete reduce la respuesta de estrés en las ovejas, lo que permitiría generar alternativas de aplicación práctica. Con este tratamiento se redujo marcadamente la frecuencia en que se observó a las ovejas costeando y caminando el día del destete, y una tendencia a vocalizar menos que el grupo control(65).

Otro manejo que reduce la respuesta de estrés es la inducción hormonal del celo de las ovejas after weaning, or if stayed in contact with two adult ewes. In addition, the animals who received these treatments of social enrichment grew more during the fattening period. At the end of the fattening period, the lambs that were in contact with the human immediately after weaned were less reactive to human manipulation.

Similarly, weaned lambs that grazed together with adult ewes presented a higher bite rate, and ruminated and grazed more than single weaned lambs(67). These results indicate that the presence of adult animals at weaning mitigates the negative effects of separation from the mother, improving the efficiency of grazing. However, this, rather than as part of social enrichment, can be part of a strategy of social facilitation accelerating feeding learning by the lambs. It was also noted that the provision of a protein supplementation after weaning reduced parasite infestation in ewes(5), improving the animals' welfare.

\section{Synthesis}

In summary, artificial weaning is a stressful event for both the ewe and lamb, affecting their health the welfare, and the productive results. While this handling is necessary to optimize the productive results, the development and implementation of management systems that reduce stress, in addition to promoting animal welfare, could have an even more positive impact on health and productive aspects. However, the available knowledge on how to reduce the negative effects of weaning is still scarce, especially considering that many of them are applicable only in specific production systems. The great variability of breeds existing in sheep productive systems makes it necessary to develop a range of tools that can impact according to the different conditions, but allowing in synthesis, to respond to the current demands of society and increase the efficiency of the production systems.

End of english version 
el día del destete, al mismo tiempo que se introducían carneros(35). Este manejo redujo el aumento de la frecuencia de vocalizaciones y en la concentración de cortisol al destete, al tiempo que puede ser aplicado en sistemas de reproducción acelerada en que interesa preñar a las ovejas tempranamente en el posparto.

También es importante el manejo que se realiza con los animales luego del destete. El enriquecimiento social posdestete mejora el bienestar de los corderos(66). La respuesta de estrés de los corderos disminuyó cuando luego del destete los corderos permanecían durante $1 \mathrm{~h}$ por día en contacto estrecho con un humano que los manejaba gentilmente (les acariciaba y les hablaba), o si permanecían en contacto con dos ovejas adultas. Además, los animales que recibieron estos tratamientos de enriquecimiento social crecieron más durante el periodo de engorde. Al finalizar el periodo de engorde, los corderos que estuvieron en contacto con el humano inmediatamente del destete fueron menos reactivos a la manipulación humana.

De manera similar, corderos destetados que pastorearon en grupos integrados también por ovejas presentaron una mayor tasa de bocados, rumiaron y pastorearon más que los corderos destetados solos(67). Estos resultados indican que la presencia de animales adultos al destete mitiga los efectos negativos de la separación de la madre mejorando la eficiencia de pastoreo. Sin embargo, esto, más que como parte del enriquecimiento social, puede ser consecuencia de una estrategia de facilitación social acelerando el aprendizaje de los corderos en su nueva alimentación. También se ha observado que la provisión de una suplementación proteica a partir del destete redujo la infestación de parásitos en corderos(5), lo que incidió positivamente sobre el bienestar de los animales.

\section{Síntesis}

En síntesis, el destete artificial es un evento estresante tanto para la oveja como para el cordero, por lo que afecta la salud y el bienestar de los animales, y los resultados productivos. Si bien este manejo es necesario para optimizar los resultados productivos, el desarrollo y aplicación de manejos que disminuyan el estrés, además de favorecer el bienestar animal, podría tener un impacto aún más positivo sobre aspectos sanitarios y productivos. Sin embargo, el conocimiento existente sobre cómo disminuir los efectos negativos del destete es aún escaso, sobre todo considerando que muchos de ellos son aplicables solamente en sistemas productivos específicos. La gran variabilidad de razas y sistemas productivos existentes en ovinos hace necesario desarrollar un abanico de herramientas que puedan tener impacto de acuerdo a las condiciones de cada uno, pero que permitan en síntesis responder a las exigencias actuales de la sociedad y aumentar la eficiencia de los sistemas productivos.

\section{LITERATURA CITADA}

1. Poindron P, Levy F, Keller M. Maternal responsiveness and maternal selectivity in domestic sheep and goats: the two facets of maternal attachment. Dev Psychobiol 2006;(49):5470.

2. Weary DM, Jasper J, Hötzel MJ. Understanding weaning distress. Appl Anim Behav Sci 2008;(110):24-41.

3. Brown TH. Early weaning of lambs. J Agric Sci 1964;(63):191-204.

4. Napolitano F, Rosa D, Sevi A. Welfare implications of artificial rearing and early weaning in sheep. Appl Anim Behav Sci 2008;(110):58-72.

5. Shaw KL, Nolan JV, Lynch JJ, Coverdale OR, Gill HS. Effects of weaning, supplementation and gender on acquired immunity to Haemonchus contortus in lambs. Int J Parasitol 1995;(25):381-387.

6. Schichowski C, Moors E, Gauly M. Effects of weaning lambs in two stages or by abrupt separation on their behavior and growth rate. J Anim Sci 2008;(86):220-225.

7. Freitas-de-Melo A, Ungerfeld R, Hötzel MJ, Abud MJ, AlvarezOxiley $A$, Orihuela $A$, et al. Mother-young behaviours at lambing in grazing ewes: Effects of lamb sex and food restriction in pregnancy. Appl Anim Behav Sci 2015;(168):3136.

8. Orgeur $P$, Mavric N, Yvore $P$, Bernard $S$, Nowak $R$, Schaal $B$, Levy F. Artificial weaning in sheep: consequences on behavioural, hormonal and immuno-pathological indicators of welfare. Appl Anim Behav Sci 1998;(58):87-103.

9. Orgeur P, Bernard S, Naciri M, Nowak R, Schaal B, Levy F. Psycological consequences of two different weaning methods in sheep. Reprod Nutr Dev 1999;(39):231-244. 
10. Freitas-de-Melo A, Banchero G, Hötzel MJ, Damián JP, Ungerfeld R. Progesterone administration reduces the behavioural and physiological responses of ewes to abrupt weaning of lambs. Animal 2013;(8):1367-1373.

11. Nowak R, Porter RH, Blache D, Dwyer CM. Behaviour and the welfare of the sheep. In: Dwyer $C$ editor. The welfare of sheep. 1rst ed. Edinburgh, United Kingdom: Springer; 2008:81-134.

12. Lynch JJ, Hinch GN, Adams DB. The behaviour of sheep: Biological principles and implications for production. Melbourne, CSIRO, (1992):126-152.

13. Poindron $P$, Le Neindre $P$. Endocrine and sensory regulation of the maternal behavior in the ewe. Adv Study Behav 1980;(11):75-119.

14. Smith FV, Van-toller C, Boyes T. The 'critical period' in the attachment of lambs and ewes. Anim Behav 1966;(14):120125.

15. Clutton-Brock TH. The evolution of parental care. 1rst ed. Princeton: Princeton University Press; 1991.

16. Lévy $F$, Keller $M$, Poindron P. Olfactory regulation of maternal behavior in mammals. Horm Behav 2004;(46):284-302.

17. Nowak $R$, Keller $M$, Val-Laillet $D$, Lévy $F$. Perinatal visceral events and brain mechanisms involved in the development of mother-young bonding in sheep. Horm Behav 2007; (52):92-98.

18. Nowak R. Senses involved in discrimination of merino ewes at close contact and from a distance by their newborn lambs. Anim Behav 1991;(42):357-366.

19. Nowak R, Lindsay DR. Discrimination of Merino ewes by their newborn lambs: important for survival? Appl Anim Behav Sci 1992;(34):61-74.

20. Hinch GN, Lecrivain E, Lynch JJ, Elwin RL. Changes in maternal-young associations with increasing age of lambs. Appl Anim Behav Sci 1987;(17):305-318.

21. Hinch GN. The suckling behaviour of triple, twin and single lambs at pasture. Appl Anim Behav Sci 1989;(22):39-48.

22. O'Connor CE, Jay NP, Nicol AM, Beatson PR. Ewe maternal behaviour score and lamb survival. Proc N Z Soc Anim Prod 1985;(45):159-162.

23. Ewbank E. Nursing and suckling behaviour amongst Clun Forest ewes and lambs. Anim Behav 1967;(15):251-258.

24. Lyford SJ. Growth and development of the ruminant digestive system. In: Curch DC editor. The Ruminant Animal. New Jersey, USA: Prentice-Hall, 1988:44-63.

25. Geraseev LC, Perez JRO, Pedreira BC, Quintão FA, Oliveira RP. Effects of pre and postnatal nutritional restriction on visceral mass growth of Santa Ines lambs. Arq Bras Med Vet Zoo 2008;(60):960-969.

26. Arnold GW, Wallace SR, Maller RA. Some factors involved in natural weaning processes in sheep. Appl Anim Ethol 1979;(5):43-50.

27. Berger J. Weaning conflict in desert and mountain bighorn sheep (Ovis canadensis): an ecological interpretation. Z Tierpsychol 1979;(50):188-200.

28. Vatankhaha M, Salehi SA. Genetic and non-genetic factors affecting Lori-Bakhtiari ewe body weight and its relationship with productivity. Small Ruminant Res 2010;(94):98-102.

29. Vatankhah M, Talebi MA, Zamani F. Relationship between ewe body condition score (BCS) at mating and reproductive and productive traits in Lori-Bakhtiari sheep. Small Ruminant Res 2012;(106):105-109.

30. Damián JP, Hötzel MJ, Banchero G, Ungerfeld R. Behavioural response of grazing lambs to changes associated with feeding and separation from their mothers at weaning. Res Vet Sci 2013;(95):913-918.

31. Weary DM, Fraser D. Signalling need: costly signals and animal welfare assessment. Appl Anim Behav Sci 1995;(44):159-169.

32. Cockram MS, Imlah P, Goddard PJ, Harkiss GD, Waran NK. The behavioural, endocrine and leucocyte response of ewes to repeated removal of lambs before the age of natural weaning. Appl Anim Behav Sci 1993;(38):127-142.

33. Stephens DB, Baldwin BA. Observations on the behaviour of groups of artificially reared lambs. Res Vet Sci 1971;(12):219-224.

34. Rhind SM, Reid HW, McMillen SR, Palmarini G. The role of cortisol and b-endorphin in the response of the immune system to weaning in lambs. Anim Sci 1998;(66):397-402.

35. Pérez-León I, Orihuela A, Lidfors L, Aguirre V. Reducing mother young separation distress by inducing ewes into oestrous into day of weaning. Anim Welf 2006;(15):383389.

36. Bush IE, Ferguson KA. The secretion of the adrenal cortex in sheep. J Endocr 1953;(10):1-8.

37. Möstl $E$, Palme R. Hormones as indicators of stress. Domest Anim Endocrinol 2002;(23):67-74.

38. Griffin JFT. Stress and immunity: A unifying concept. Vet Immunol Immun 1989;(20):263-312.

39. Blecha F, Pollman DS, Nichols DA. Weaning pigs at an early age decreases cellular immunity. Can J Vet Res 1986;(4):522525.

40. Lynch EM, Earley B, McGee M and Doyle S. Characterisation of physiological and immunological responses in beef cows to abrupt weaning and subsequent housing. BMC Vet Res 2010;(6):37.

41. Ungerfeld R, Hotzel MJ, Scarsi A, Quintans G. Behavioral and physiological changes in early-weaned multiparous and primiparous beef cows. Animal 2011;(8):1270-1275.

42. Napolitano F, Marino V, De Rosa G, Capparelli R, Bordi A. Influence of artificial rearing on behavioral and immune response of lambs. Appl Anim Behav Sci 1995;(45):245253.

43. Watson DL, Gill HS. The effect of weaning on antibody responses and nematode parasitism in Merino lambs. Res Vet Sci 1991;(51):128-132.

44. Lee GJ, Harris D, Ferguson BD, Jelbart RA. Growth and carcass fatness of ewe, wether, ram and cyptorchid crossbred lambs reared at pasture: effects of weaning age. Aust J Exp Agr 1990;(30):743-747.

45. Caneque V, Velasco S, Diaz M, Perez C, Huidobro F, Lauzurica $\mathrm{S}$, et al. Effects of weaning age and slaughter weight on carcass and meat quality of Talaverana breed lambs raised at pasture. Anim Sci 2001;(73):85-95.

46. Schichowski C, Moors E, Gauly M. Influence of weaning age and an experimental Haemonchus contortus infection on behaviour and growth rates of lambs. Appl Anim Behav Sci 2010;(125):103-108. 


\section{DESTETE ARTIFICIAL EN OVINOS: RESPUESTA DE ESTRÉS Y BIENESTAR ANIMAL}

47. Geenty KG. Influence of weaning age, management, and slaughter age on export lamb carcass production and slipe wool weights. N Z J Agric Res 1980;(23):433-440.

48. Gaili E. Effect of weaning age on postweaning feedlot performance and carcass characteristics of Najdi lambs. World Rev Anim Prod 1992;(27):61.

49. Langland JP, Donald GE. The intakes and growth rate of grazing Border Leicester X Merino lambs weaned at 21, 49, and 77 days. Anim Prod 1975;(21):175-181.

50. Aksakal V, Ebru E, Memis O, Muhlis M. Effects of various ages of weaning on growth performance of Morkaraman lambs. J Anim Vet Adv 2009;(8):1551-1554.

51. Gaudin S, Chaillou E, Cornilleau F, Moussu C, Boivin X, Nowak R. Daughters are more strongly attached to their mother than sons: a possible mechanism for early social segregation. Anim Behav 2015;(102):33-43.

52. Hernandez CE, Matthwes LR, Oliver MH, Bloomfield FH, Harding JE. Effects of sex, litter size and periconceptional ewe nutrition on the ewe-lamb bond. Appl Anim Behav Sci 2009;(120):76-83.

53. Hernandez CE, Matthews LR, Oliver MH, Bloomfield FH, Harding JE. Effects of sex, litter size and periconceptional ewe nutrition on offspring behavioural and physiological response to isolation. Physiol Behav 2010;(101):588-594.

54. Festa-Bianchet $M$, Jorgenson JT, Wishart WD. Early weaning in bighorn sheep, Ovis canadensis affects growth of males but not of females. Behav Ecol 1994;(5):21-27.

55. Folstad I, Karter AJ. Parasites, bright males and the immunocompetence handicap. American Naturalist 1992;(139):603-622.

56. Barger IA. Influence of sex and reproduction status on susceptibility of ruminants to nematode parasitism. Int J Parasitol 1993;(23):463-469.

57. Sarasa M, Rambozzi L, Rossi L, Meneguz PG, Serrano E, Granados JE, et al. Sarcoptes scabiei: Specific immune response to sarcoptic mange in the Iberian ibex Capra pyrenaica depends on previous exposure and sex. Exp Parasitol 2010;(124):265-271.

58. Seibert B, Gauly M, Erhardt G. Productivity of different sheep breeds in extensive pasture management. Arch Tierz 2004;(47):147-152.
59. Freitas-de-Melo $A$, Ungerfeld $R$, Pérez-Clariget $R$. Cruzamientos ovinos Texel por Corriedale: I. Comportamiento alimenticio y crecimiento corporal de los corderos. Aceptado para su presentación en XXIV Congreso de la Asociación Latinoamericana de Producción Animal (ALPA). Puerto Varas. Chile. 2015.

60. Freitas-de-Melo A, Ungerfeld R, Pérez-Clariget $R$. Cruzamientos ovinos Texel por Corriedale: II. Respuesta comportamental de los corderos al destete. Aceptado para su presentación en XXIV Congreso de la Asociación Latinoamericana de Producción Animal (ALPA). Puerto Varas. Chile. 2015.

61. Dwyer CM, Lawrence AB, Bishop SC, Lewis M. Ewe-Lamb bonding behaviours at birth are affected by maternal undernutrition in pregnancy. Brit J Nut 2003;(89):123-136.

62. Olazabal-Fenochio A, Vera-Ávila HR, Serafín-López N, Medrano-Hernández JA, Sánchez-Saucedo $\mathrm{H}$, Terrazas-García AM. Reconocimiento mutuo madre-cría en ovinos Columbia con restricción nutricional durante la gestación. Rev Mex Cienc Pecu 2013;4(2):127-147.

63. Freitas-de-Melo A, Ungerfeld R, Abud MJ, Pérez-Clariget $R$. Behavioural response of lambs weaned from ewes that grazed in two pasture allowances in pregnancy. Ann Meet European Fed Anim Sci (EAAP). Varsovia; Polonia. 2015:367.

64. Orihuela A, Suárez E, Vázquez R. Effect of restricting suckling on the social bond between ewes and their 10-week-old lambs. Livest Prod Sci 2004;(87):259-264.

65. Freitas-de-Melo A, Ungerfeld R, Pérez-Clariget $R$. Progesterone administration reduces the behavioural response of ewes at weaning. Ann Meet European Fed Anim Sci (EAAP). Varsovia; Polonia. 2015:369.

66. Pascual-Alonso M, Miranda-de la Lama GC, Aguayo-Ulloa L, Ezquerro L, Villarroel M, Marín RH, Maria GA. Effect of postweaning handling strategies on welfare and productive traits in lambs. J Appl Anim Welf Sci 2015;18(1):42-56.

67. Youssef MYI, Philips CJC, Metwally M. The effect of preweaning grazing experience and presence of adult ewes on grazing behaviour of weaned lambs. Appl Anim Behav Sci 1995;(44):257-281. 